\title{
Mapping 2007-08 Tuition And Fees In Higher Education
}

Brian T. Kench, University of Tampa, USA

H. Scott Wallace, University of Wisconsin-Stevens Point, USA

\begin{abstract}
Using data sets from US News \& World Report and the Association to Advance Collegiate Schools of Business, this paper isolates 10 factors that account for 90 percent of the variation in tuition and fees across 523 institutions of higher learning in the United States. It is hoped that the results will give guidance to schools by quantifying the costs and benefits of making a given change to their tuition and fee structure.
\end{abstract}

Keywords: US Higher Education, Mapping, Tuition \& Fees

\section{INTRODUCTION}

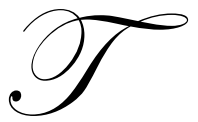

he degree of heterogeneity among institutions of higher learning in the United States is considerable. Four year schools are differentiated across a wide variety of attributes: public/private, liberal arts/regional comprehensive, graduate/bachelors, research/teaching, and religious/secular. In addition, many colleges and universities focus their resources in excelling in specialized fields (economics at the University of Chicago, for example). This diversity is a great strength and is one of the reasons why the United States remains the world leader in education at the university level.

The attributes colleges and universities possess obviously are critical in determining the choices of attendees. Yet, administrative decisions regarding the level of tuition and fees often are haphazard and unrelated to the strengths of the university's programs. In an era of declining taxpayer support and unfavorable demographic trends, public institutions, in particular, need to set tuition to the specific benefits that they offer students. To do this wisely, schools must assess their competitive positions vis-à-vis other institutions. Using data sets from US News \& World Report and the Association to Advance Collegiate Schools of Business (hereafter AACSB), this paper offers a model that isolates 10 factors that account for 90 -percent of the variation in tuition and fees across 523 institutions of higher learning. One goal of this analysis is to assist administrators in their task of determining the appropriate level of tuition and fees given their competitive position in their respective markets.

\section{MAPPING COMPETITIVE MARKETS}

The theoretical foundation that underpins the analysis used in this paper dates back to the 1960s with the work of economist Kelvin Lancaster (Lancaster, 1966). In a paper published in the Journal of Political Economy, Lancaster introduced a new approach to consumer theory that emphasized the importance of product characteristics in the utility maximizing choices of consumers. This characteristics approach "assumes that consumer demand is directed not towards products per se but rather towards product characteristics. For example, when searching for a computer, consumers look for microprocessor speed, RAM capacity, hard disk capacity, screen size, and so forth. A consumer's valuation for a particular computer is the sum of the valuations for each particular characteristic" (Cabral, 2000, 207). The chararacteristics approach has led to efforts in developing empirical methods for hedonic models, which are used to estimate the demand for consumer products. Drawing upon data on car models sold in the US from 1971 to 1990, economists, for example, have estimated "own- and cross-price elasticities as well as elasticities of demand with respect to vehicle attributes (such as weight or fuel efficiency)" (Berry, et. al., 1995, 841). The value of this analysis is not limited to the economics discipline. "[T] a useful framework for business strategy. For example, a computer manufacturer may obtain an estimate of the willingness to pay for a new computer by estimating valuations for characteristics from previous sales data" (Cabral, 2000, 209). 
In a recent paper from Harvard Business Review, Richard A. D' Aveni (2007) has introduced a method for organizations to create a "price-benefit positioning map." "In its simplest form, a price-benefit positioning map shows the relationship between the primary benefit that a product provides to customers and the prices of all the products in a given market" (D'Aveni, 2007, 112). The author outlines a number of steps that need to be completed in creating a "price-benefit positioning map." First, the firm must define the relevant market for its product. This requires that it identify other products that are similar to the firm's own product in the sense that they satisfy the same consumer needs. In addition, firms must define the geographic region within which competition occurs. Second, firms need to collect data on prices of these products and on the benefits that these products provide to consumers. Drawing on this data, firms then perform regression analysis to find the relationship between product price (the dependent variable) and product benefits (the independent variables). Third, try to isolate the primary benefit (or group of correlated benefits) that accounts for the greatest variation in prices among competing products (D’Aveni, 2007).

Building on the above analysis, this paper seeks to isolate the variables that explain the variation in tuition and fees across institutions of higher education in the United States. The results will give guidance to enrolment management personal at colleges and universities by quantifying the costs and benefits of making a given change to their tuition and fee structure.

\section{DATA, MODEL AND RESULTS}

The data sources are US News \& World Report Best Colleges 2008 (hereafter USNWR) and the AACSB. ${ }^{1}$ Prospective students have the opportunity to consider a variety of colleges and universities across the United States. Thus, we have used the U.S. the relevant geographic market for higher education. Within this geographic market we have included, from the 2008 USNWP, the top 70 mid-western master's level universities, the top 89 northern master's level universities, the top 61 southern master's level universities, the top 61 western master's level universities, the top 130 national universities, and the top 125 top liberal arts colleges. From these 535 institutions, 13 have been dropped from the dataset because of incomplete information was provided. ${ }^{2}$ Thus, the dataset used here contains 523 observations. ${ }^{3}$

The AACSB data set details those colleges or universities that are accredited by AACSB. The mission of AACSB is to advance quality management education worldwide through accreditation and through leadership. Having the AACSB accreditation is thought to be a signal of educational excellence. Thus, we hypothesize that students are willing to pay more for colleges and universities with the AACSB designation.

The dependent variable is the "tuition and fees" for the 2007-2008 academic year. We report the results of two OLS regressions below. The first uses in-state tuition and fees for public institutions and the second uses outof-state tuition and fees for public institutions. The tuition and fees amount for private institutions is the same in both regressions reported below.

The model:

$Y=a+b_{1} *$ Secular+ $b_{2} *$ Private $+b_{3} * A A C S B+b_{4} *$ Mid-West $+b_{5} *$ South $+b_{6} *$ West $+b_{7} *$ Masters $+b_{8} *$ PhD +
$b_{9} *$ Percent $<20+b_{10} *$ Percent $>50+b_{11} *$ Student_Faculty_Ratio $b_{12} * U G_{-}$Student_POP $+b_{13} *$ Masters_Mid-West_Ranking
$+b_{14} *$ Masters_North_Ranking $+b_{15} *$ Masters_South_Ranking $+b_{16} *$ Masters_West_Ranking $+b_{17} *$ National_Ranking +
$b_{18} *$ Liberal_Arts_Ranking $+m$.

The Secular dummy variable has institutions with no religious affiliation $=1$ and institutions that are religiously affiliated $=0$. The Private dummy variable has private institutions $=1$ and public institutions $=0$. The $A A C S B$ dummy variable has institutions with the AACSB accreditation are $=1$ and those without the accreditation $=$ 0 .

\footnotetext{
${ }^{1}$ See data are found at www.usnews.com and www.aacsb.edu.

${ }^{2}$ The following schools were dropped from the dataset: Bates College, Centre College, Colby College, College of Santa Fe , Connecticut College, Gallaudet University, Middlebury College, Principia College, Regis College, Union College, US Military Academy, US Naval Academy, and University of South Alabama.

${ }^{3}$ Our data represent 23 percent of all colleges and universities in the U.S. Although we too prefer an analysis of the total population, limited data have constrained our analysis to the available the sub-group.
} 
USNWR divides the United States into four regions: north, mid-west, south, and west. Three dummy variables have been created to capture regional differences as defined by USNWR. First, the dummy variable MidWest equals 1 if the school is in the mid-west, otherwise it equals 0. Second, the dummy variable South equals 1 if the school is in the south $=1$, otherwise it equals 0 . Third, the dummy variable West equals 1 if the school is in the west, otherwise it equals 0 . Regional differences are all measured relative to institutions located in the northern region.

USNWR also categorizes institutions as national, masters, or liberal arts, which turn out to be proxies for the highest degree awarded. At all national universities, the highest degree awarded is a $\mathrm{PhD}$; at all masters universities, the highest degree awarded is a masters; and at all liberal arts colleges, the highest degree awarded is a bachelors. Thus, we create two dummy variables to measure variations because of highest degree awarded. First, the dummy variable Masters has institutions that award masters level degrees equal to 1 , all others equal 0 . Second, $P h D$ has institutions that award $\mathrm{PhD}$ level degrees equal to 1 , all others equal 0 . The differences in this category are measured relative to institutions where a bachelors degree is the highest degree awarded.

The variable Percent $<20$ equals the percent of classes with less than 20 students. The variable Percent $>50$ equals the percent of classes with greater than 50 students. The variable Student_Faculty_Ratio equals the student faculty ratio. The variable $U G_{-}$Student_POP equals the undergraduate student population.

The final set of six variables have been created to capture the effect of begin ranked in USNWR. The first variable is Masters_Mid-West_Ranking. This variable equals the institution's mid-west masters ranking in USNWR, for institutions not in the mid-west masters ranking equals 0 . The remaining five variables, i.e., Masters_North_Ranking, Masters_South_Ranking, Masters_West_Ranking, National_Universities_Ranking, and Liberal_Arts_Ranking are structured similarly.

Table 1: Full Regression Estimates: Ordinary Least Squares of a Tuition \& Fees (In-State).

\begin{tabular}{|c|c|c|c|c|c|}
\hline Parameter & Estimate & Error & $t$ & $p>|t|$ & VIF \\
\hline (Constant) & 24420.49 & 1892.945 & 13.429 & .000 & -- \\
\hline Secular & 1370.44 & 442.353 & 3.098 & .002 & 1.975 \\
\hline Religious & 0 & & & & \\
\hline Private & 17229.97 & 640.512 & 26.900 & .000 & 3.700 \\
\hline Public & 0 & & & & \\
\hline AACSB & 1685.50 & 436.151 & 3.857 & .000 & 1.984 \\
\hline No AACSB & 0 & & & & \\
\hline Mid-West & -2793.39 & 542.327 & -5.151 & .000 & 2.314 \\
\hline North & 0 & & & & \\
\hline South & -5508.86 & 581.513 & -9.473 & .000 & 2.307 \\
\hline West & -2391.03 & 576.759 & -4.146 & .000 & 2.285 \\
\hline Bachelors & 0 & & & & \\
\hline Masters & -10050.57 & 917.548 & -10.954 & .000 & 8.780 \\
\hline $\mathrm{PhD}$ & -1067.80 & 1083.003 & -.986 & .325 & 9.181 \\
\hline Percent $<20$ & -51.28 & 17.054 & -3.007 & .003 & 2.825 \\
\hline Percent $>50$ & -182.86 & 53.973 & -3.388 & .001 & 4.164 \\
\hline Student_Faculty_Ratio & -157.16 & 75.777 & -2.074 & .039 & 3.389 \\
\hline UG_Student_POP & -.12 & .039 & -3.022 & .003 & 3.818 \\
\hline Masters_Mid-West_Ranking & -61.61 & 16.899 & -3.646 & .023 & 2.299 \\
\hline Masters_North_Ranking & -72.96 & 12.617 & -5.782 & .000 & 2.340 \\
\hline Masters_South_Ranking & -38.13 & 20.441 & -1.865 & .063 & 2.198 \\
\hline Masters_West_Ranking & -80.03 & 20.677 & -3.871 & .002 & 2.249 \\
\hline National_Universities_Ranking & -79.64 & 9.506 & -8.378 & .000 & 4.162 \\
\hline Liberal_Arts_Ranking & -86.65 & 9.905 & -8.748 & .000 & 4.001 \\
\hline
\end{tabular}


Table 1 reports the OLS regression results of our model when the dependant variable is in-state tuition and fees for public institutions. Only the coefficient for $P h D$ is statistically insignificant, which reveals that no statistical difference exists, ceteris paribus, in tuition and fees at institutions where the highest degree awarded is a bachelor's and institutions where the highest degree awarded is a $\mathrm{PhD}$.

The constant in Table 1 equals $\$ 24,420.49$. This is the baseline "tuition and fees" from which the other significant coefficients are added or subtracted. The tuition and fees at the 311 secular institutions, ceteris paribus, is higher by $\$ 1,370.44$. The tuition and fees at the 356 private institutions, ceteris paribus, is higher by $\$ 17,229.97$. This may also be read as the average dollar amount of federal, state, and local subsidies per student at public institutions in the 2007-08 academic year. An open question is whether or not this amount is too high or too low. ${ }^{4}$

In our dataset, 246 institutions are accredited by AACSB. The tuition and fees at institutions with the AACSB accreditation, ceteris paribus, is $\$ 1,685.50$ higher relative to non-AACSB accredited institutions.

To measure regional difference in tuition and fees we used USNWRs regional categorization, which resulted in 131 western, 177 northern, 107 southern, and 108 western institutions. Dummy variables were used for each region. Relative to institutions in the north, the tuition and fees at institutions located in the mid-west, ceteris paribus, is lower by $\$ 2,793.39$. Relative to institutions in the north, the tuition and fees at institutions in the south, ceteris paribus, is lower by $\$ 5,508.86$. Relative to institutions in the north, the tuition and fees at institutions in the west, ceteris paribus, is lower by $\$ 2,391.03$. It is interesting to observe the deep discount for southern institutions --nearly double that of institutions in the mid-west and more than double that of institutions in the west.

By focusing on the highest degree earned at an institution, we find that there is no statistical difference, ceteris paribus, between the 116 institutions that only award a bachelors degree and the 130 institutions that award $\mathrm{PhDs}$. However, relative to institutions that only award a bachelors degree, institutions where the highest degree awarded is a masters have a tuition and fees amount that, ceteris paribus, is lower by $\$ 10,150.57$. There are at least two possible explanations for this market response. First, masters degree programs typically charge higher tuition and fees, and thus some pressure to raise undergraduate tuition and fees is diminished. The second, and the more pessimist perspective, is that schools that offer masters degree programs spread themselves too thin. A variety of resources are funneled into the masters degree programs at the expense of the undergraduate degree program, and the effect of this diminution is measured by the market in the form of lower tuition and fees for institutions in this category. Administrators are often uncertain of the opportunity costs of their actions. And in many cases administrators only count the benefits, e.g., tuition and fees from masters degree programs, and fail to adequately measure all of the indirect costs. The coefficient on the variable Masters offers a market measure of the opportunity cost of having a masters degree program.

The variables Percent $<20$ and Percent $>50$ capture the marginal effects of changing the number of seat offered in each class. The mean reported number of classes with less than 20 students equals $53.92 \%$. The coefficient of Percent $<20$ reveals that if the percent of classes with less than 20 students increases by one percent, all else equal, tuition and fees decrease by $\$ 51.28$. This unexpected results reveals that consumers place a negative value on an institution's decision to increase the percentage of classes with less than 20 students, ceteris paribus.

The mean reported number of classes with greater than 50 students equals $5.026 \%$. The coefficient of Percent $>50$ reveals that if the percent of classes with greater than 50 students decreases by one percent, all else equal, tuition and fees increase by $\$ 182.86$. This result suggests that lowering the percent of classes with 50 or more student generates a bigger bang for the buck than increasing the percent of classes with less than 20 students. The cost of hiring new faculty is clear. Now the monetary benefits associated with changing class size is also clear.

Faculty-to-student ratios are commonly advertised in an effort to attract prospective students. Of the 523 institutions in our dataset, the mean student to faculty ratio is 13.63 . The marginal effect of decreasing this ratio by one percent point, ceteris paribus, is a $\$ 157.16$ increase in tuition and fees.

${ }^{4}$ Future research will quantify how this subsidy to public institutions has changed over time. 
The mean undergraduate student population in our dataset is 6,695. The coefficient if $U G_{-}$Student_POP reveals that increasing the undergraduate population by one student leads to a $\$ 0.12$ decrease in tuition and fees. The law of demand holds true even in the market for higher education. By using the mean tuition and fees amount of $\$ 20,619$, the mean undergraduate student population of 6696 , and the coefficient of $U G_{-}$Student_POP, we can calculate the price elasticity of demand coefficient; it equals $-25.66 .^{5}$ This reveals that the market for higher education is relatively elastic.

The remaining set of variables show the effect of a marginal change in an institution's USNWR ranking. First, a marginal increase in a mid-western masters level institution's ranking increases tuition and fees by $\$ 61.61$. Second, a marginal increase in a northern masters level institution's ranking increases tuition and fees by $\$ 72.96$. Third, a marginal increase in a southern masters level institution's ranking increases tuition and fees by $\$ 38.13$. Fourth, a marginal increase in a western masters level institution's ranking increases tuition and fees by $\$ 80.03$. Fifth, a marginal increase in a national university's ranking increases tuition and fees by $\$ 79.64$. Finally, a marginal increase in a liberal art college's ranking increases tuition and fees by $\$ 86.65$. It is clear that USNWR rankings matter everywhere in our model except at masters level institutions in the southern region of the U.S. In addition, the USNWR ranking seems to matter most at liberal arts colleges.

Table 2: Full Regression Estimates: Ordinary Least Squares of a Tuition \& Fees (Out-Of-State).

\begin{tabular}{|c|c|c|c|c|c|}
\hline Parameter & Estimate & Error & $t$ & $p>|t|$ & VIF \\
\hline (Constant) & 32535.81 & 1983.164 & 16.406 & .000 & -- \\
\hline Secular & 876.52 & 463.434 & 1.891 & .059 & 1.975 \\
\hline Religious & 0 & & & & \\
\hline Private & 8062.36 & 671.036 & 12.015 & .000 & 3.700 \\
\hline Public & 0 & & & & \\
\hline AACSB & 1148.51 & 459.937 & 2.513 & .012 & 1.984 \\
\hline No AACSB & 0 & & & & \\
\hline Mid-West & -2374.52 & 568.172 & -4.179 & .000 & 2.314 \\
\hline North & 0 & & & & \\
\hline South & -4137.08 & 609.228 & -6.791 & .000 & 2.307 \\
\hline West & -1350.95 & 604.245 & -2.236 & .026 & 2.285 \\
\hline Bachelors & 0 & & & & \\
\hline Masters & -10025.63 & 961.275 & -10.430 & .000 & 8.780 \\
\hline $\mathrm{PhD}$ & 7.12 & 1134.615 & .006 & .995 & 9.181 \\
\hline Percent $<20$ & -32.30 & 17.866 & -1.808 & .071 & 2.825 \\
\hline Percent $>50$ & -74.86 & 56.545 & -1.324 & .186 & 4.164 \\
\hline Student_Faculty_Ratio & -104.66 & 79.388 & -1.318 & .188 & 3.389 \\
\hline UG_Student_POP & -.07 & .041 & -1.595 & .111 & 3.818 \\
\hline Masters_Mid-West_Ranking & -94.58 & 17.704 & -5.342 & .000 & 2.299 \\
\hline Masters_North_Ranking & -84.49 & 13.219 & -6.391 & .000 & 2.340 \\
\hline Masters_South_Ranking & -82.71 & 21.415 & -3.862 & .000 & 2.198 \\
\hline Masters_West_Ranking & -115.76 & 21.662 & -5.344 & .000 & 2.249 \\
\hline National_Universities_Ranking & -91.06 & 9.959 & -9.144 & .000 & 4.162 \\
\hline Liberal_Arts_Ranking & -88.21 & 10.377 & -8.501 & .000 & 4.001 \\
\hline
\end{tabular}

Table 2 reports the full OLS regression results when the dependant variable contains out of state tuition and fee for public institutions. As was the case in Table 1, the variable $P h D$ is not significant. In addition, in Table 2, the variables Percent>50,Student_Faculty_Ratio, and $U_{-}{ }_{-}$Student_POP are no longer statistically significant.

${ }^{5}$ The formula to calculate the price elasticity of demand equal $(1 / \mathrm{b}) * \mathrm{P} / \mathrm{Q}$, where $\mathrm{b}=\mathrm{DP} / \mathrm{DQ}$. In this case $(1 / \mathrm{b})=$ the coefficient of $U G \_S t u d e n t \_P O P, \mathrm{P}=$ the average tuition and fees, and $\mathrm{Q}=$ the average undergraduate student population. Price elasticity of demand coefficients may also be calculated for individual schools by substituting in the institution's tuition and fees amount and the institution's undergraduate student population. 
Table 3: Five Overpriced and Five Underpriced Institutions (when a public institution's in-state tuition and fees has been entered as the dependent variable)

\begin{tabular}{|ll|c|c|c|}
\hline \multicolumn{1}{|c|}{ Institution } & $\begin{array}{c}\mathbf{2 0 0 7 - 0 8} \\
\text { Tuition \& Fees }\end{array}$ & $\begin{array}{c}\text { Predicted } \\
\text { Tuition \& Fees }\end{array}$ & Difference \\
\hline 1. & New York University & $\$ 35,283$ & $\$ 24,528$ & $\$ 10,755$ \\
\hline 2. & Dominican University of California & $\$ 30,570$ & $\$ 27,341$ & $\$ 3,229$ \\
\hline 3. & Hampshire College (MA) & $\$ 36,545$ & $\$ 34,139$ & $\$ 2,406$ \\
\hline 4. & Rollins College & $\$ 32,640$ & $\$ 30,974$ & $\$ 1,666$ \\
\hline 5. Bennington College (VT) & $\$ 36,800$ & $\$ 35,649$ & $\$ 1,151$ \\
\hline & & & & $-\$ 31,649$ \\
\hline 1. & Berea College & $\$ 776$ & $\$ 32,425$ & $-\$ 30,099$ \\
\hline 2. & Brigham Young University & $\$ 3,620$ & $\$ 33,719$ & $-\$ 24,399$ \\
\hline 3. Howard University & $\$ 14,020$ & $\$ 38,419$ & $-\$ 15,954$ \\
\hline 4. & Rice University & $\$ 26,106$ & $\$ 42,060$ & $-\$ 15,893$ \\
\hline 5. Wells College & $\$ 17,810$ & $\$ 33,703$ & \\
\hline
\end{tabular}

Table 4: Five Overpriced and Five Underpriced Institutions (when a public institution's out-out-state tuition and fees has been entered as the dependent variable)

\begin{tabular}{|c|c|c|c|}
\hline Institution & $\begin{array}{c}\text { 2007-08 } \\
\text { Tuition \& Fees }\end{array}$ & $\begin{array}{c}\text { Predicted } \\
\text { Tuition \& Fees }\end{array}$ & Difference \\
\hline 1. Dominican University of California & $\$ 30,570$ & $\$ 24,931$ & $\$ 5,639$ \\
\hline 2. Lynchburg College & $\$ 27,215$ & $\$ 22,240$ & $\$ 4,975$ \\
\hline 3. Hampshire College (MA) & $\$ 36,545$ & $\$ 31,709$ & $\$ 4,836$ \\
\hline 4. University of Minnesota-Duluth & $\$ 20,146$ & $\$ 15,751$ & $\$ 4,395$ \\
\hline 5. $\quad$ Rollins College & $\$ 35,283$ & $\$ 28,854$ & $\$ 3,786$ \\
\hline 1. $\quad$ Berea College & $\$ 776$ & $\$ 31,397$ & $-\$ 30,621$ \\
\hline 2. Brigham Young University & $\$ 3,620$ & $\$ 33,134$ & $-\$ 29,514$ \\
\hline 3. Howard University & $\$ 14,020$ & $\$ 34,333$ & $-\$ 20,313$ \\
\hline 4. SUNY College of Environmental Science and Forestry & $\$ 11,426$ & $\$ 26,576$ & $-\$ 15,150$ \\
\hline 5. $\quad$ Rice University & $\$ 26,106$ & $\$ 40,176$ & $-\$ 14,070$ \\
\hline
\end{tabular}

\section{SUMMARY AND CONCLUSIONS}

It is hoped that administrators at colleges and universities around the United States will use the results of our model as a road map to help guide them in pricing their product optimally. In addition, the results offered here give important clues as to how the market would respond to decisions that institutions could make. For example, the data reveal that students are willing to pay more to lower the percent of class with greater than 50 students. If budgets are tight, and we know that they are, then institutions should focus on decreasing the number classes with more than 50 students before they increase the number of classes with less than 20 students.

In addition, if your institution has a business school, it might be worth the enormous effort of gaining an AACSB accreditation. The data suggest that by adopting AACSB's standards for a quality management education, the institution as a whole seems to gain a positive externality. Administrators are often curious as to whether gaining an AACSB accreditation is worth the significant hurdles an institution must go over; the short answer is yes it is worth the effort. Our data reveals that the market is by willing to pay between $\$ 1,148.51$ and $\$ 1,685.50$ more per student in tuition and fees at institutions with an AACSB accreditation.

In addition, the data reveal that institutions should pay attention to their USNWR ranking. Students are willing to pay more for institutions with a higher rank. Finally, institutions where a master's is the highest degree awarded need to take note. Something interesting is happening in the market such that undergraduate students are paying less than bachelors institutions (and institutions with a $\mathrm{PhD}$ ), all else equal, by $\$ 10,025.63$ and $\$ 10,050.57$ per student. Administrators should be concerned about entering this segment of the marketplace because the aggregate behavior of consumers has certainly signaling that something strange is going on. 


\section{AUTHOR INFORMATION}

Brian T. Kench received his Ph.D. in Economics from the University of Connecticut in 2000. His academic research involves experimental economics, the economics of organization, and the economics of regulation. He has been published in Journal of Regulatory Economics, Journal of Economic Development and Business Policy, Journal of Business Disciplines, and Journal of Financial Transformation. He has forthcoming articles in Eastern Economic Journal and Journal of Economics and Economic Education Research. Dr. Kench is Associate Professor and Chair of Economics in the Sykes College of Business at the University of Tampa where he earned the 2009 Teaching Excellence Award.

H. Scott Wallace, In 1999, H. Scott Wallace completed his Ph.D. in economics at the University of Connecticut. His research interests include organizational economics, industrial organization, business economics, and economic history. Scott has published in Journal of Business Disciplines and the Journal of Contemporary Business Issues. He has led two trips abroad with students focusing on International Retailing in Europe. He currently holds the rank of Associate Professor at the University of Wisconsin - Stevens Point and also is the Research Associate at the Central Wisconsin Economic Research Bureau.

\section{ACKNOWLEDGEMENTS}

Radmila Marinkovic provided able research assistance.

\section{BIBLIOGRAPHY}

1. Berry, S., Levinsohn, J., and Ariel Pakes. 1995. "Automobile Prices in Market Equilibrium," Econometrica, Vol. 63, pp. 841-890.

2. Cabral, Luis. 2000. Introduction to Industrial Organization. Cambridge: The MIT Press.

3. D' Aveni, Richard. 2007. "Mapping Your Competitive Position," Harvard Business Review, November, pp. 110-120.

4. Lancaster, Kevin. 1966. "A New Approach to Consumer Theory," Journal of Political Economy, Vol. 74, No. 2, April, pp. 132-157. 